\title{
Disappearance of Proceratophrys moratoi in its type locality by anthropogenic environmental changes
}

\section{Desaparecimento de Proceratophrys moratoi em sua localidade tipo, devido a alterações antrópicas em seu ambiente}

\author{
Daniel Contieri Rolim ${ }^{1}$, Silvio César de Almeida ${ }^{2}$
}

\begin{abstract}
Many cases of species decline or disappearance are being documented worldwide, primarily related to change and loss of habitat. We present strong evidences on the disappearance of Proceratophrys moratoi in its type locality, the area of Botucatu, São Paulo, and south eastern Brazil. Between August 2006 and December 2008 we exhaustively search for the species in its two occurrence areas in Botucatu. However, the species was not recorded in these areas. The species has high specificity and low plasticity regarding environment occupation, and does not adapt to the anthropogenic changes in its habitat. These data demonstrate the need to protect the occurrence areas of Proceratophrys moratoi, especially as a full protection reserve to guarantee the survival of the remaining populations.
\end{abstract}

Keyword: Amphibia. Brazil. Cerrado. Threatened species.

\section{Resumo}

Muitos casos de declínio ou desaparecimento de espécies estão sendo documentados em todo o mundo, principalmente relacionados à modificação e perda de habitat. Nós apresentamos fortes evidências do desaparecimento de Proceratophrys moratoi nas áreas de ocorrência conhecida em sua localidade tipo: Botucatu, São Paulo, sudeste do Brasil. Entre agosto de 2006 e dezembro de 2008 nós fizemos amostragens exaustivas na busca pela espécie, nas duas áreas de ocorrência da espécie em Botucatu. No entanto, a espécie não foi registrada nessas áreas. A espécie possui alta especificidade e baixa plasticidade na ocupação do ambiente, não se adaptando as mudanças antrópicas em seu habitat. Estes dados demonstram a importância da conservação das áreas de ocorrência da espécie, principalmente na forma de reserva de proteção integral para garantir a sobrevivência das populações de Proceratophrys moratoi.

Palavras chave: Amphibia. Brasil. Cerrado. Espécie ameaçada.

\footnotetext{
${ }^{1}$ Doutorado em Ciências Biológicas pelo Instituto de Biociências de Botucatu da Universidade Estadual Paulista Júlio de Mesquita Filho. Secretaria Municipal do Meio Ambiente de Bauru (SEMMA); Bauru, São Paulo, Brasil. E-mail: danielcrolim@gmail.com

${ }^{2}$ Doutorado em Ciências Biológicas pelo Instituto de Biociências de Botucatu da Universidade Estadual Paulista Júlio de Mesquita Filho. Departamento de Zoologia, Instituto de Biociências, Universidade Estadual Paulista Júlio de Mesquita Filho; Botucatu, São Paulo, Brasil.
} 


\section{Introdução}

The disappearance and decline of amphibian populations increased worldwide, along the recent decades (BEEBEE, 2002; COHEN JUNIOR, 2001; HEYER et al., 1988; HOULAHAN et al., 2000; LIPS et al., 2005; POUNDS, 1996; SHERMAN; MORTON, 1993; WEYGOLDT, 1989; YOUNG et al., 2001). Several factors are singled out as responsible for the local disappearance of amphibian species: environmental pollution (BOONE; JAMES, 2003; HAYES, 1997) acid rain (HARTE; HOFFMAN, 1989; SPARLING, 1995), ultraviolet radiation (BLAUSTEIN et al., 1994; LIZANA; PEDRAZA, 1998), diseases (CAREY, 1993; CRAWFORD; LIPS; BERMINGHAM, 2010; LIPS, 1998, 1999), introduction of alien species (JENNINGS; HAYES, 1985; KATS; FERRER, 2003), climate changes (ARAÚJO; THUILLER; PEARSON, 2006; HEYER et al., 1988; POUNDS; CRUMP et al., 1994; POUNDS; FOGDEN; CAMPBELL, 1999), illegal trade of wild animals (PISTONI; TOLEDO, 2010; SALAS, 1995) and generalized man-made environmental changes (ADAMS, 1999; BEEBEE et al., 1990). The loss of habitat is the highest threat to most imperiled vertebrate species, because disruption caused by humans have altered, degraded and destroyed the landscape in large-scale, causing the extinction of species and communities (BECKER et al., 2007; PRIMACK; RODRIGUES, 2001; VALLAN, 2002). On the other hand, many amphibian populations are highly variable in abundance from year to year, so long-term studies are needed to determine if certain species are actually declining or merely going through a population fluctuation (BRODMAN; CORTWRIGHT; RESETAR, 2002; GREEN, 2003; MARSH, 2001; PEACHMANN et al., 1991).

Proceratophrys moratoi was described by Jim and Caramaschi (1980), from specimens collected at Rubião Júnior district $\left(22^{\circ} 53^{\prime} 36^{\prime \prime} \mathrm{S}, 48^{\circ} 30^{\prime} 04^{\prime \prime} \mathrm{W}\right)$, Botucatu city, São Paulo state, southeastern Brazil (Holótipo captured on September 22, 1976 and 25 Parátipos collected between September, 1976 and December, 1977). The authors quote that the species occurs in environments with open phytophysiognomy, occupying areas adjacent to a small stream with herbaceous vegetation predominating over shrubs and scattered trees. Tadpoles are found in shallow water with slow flow at areas shaded by shrubs and trees (ROSSA-FERES; JIM, 1996).

Since description, $P$. moratoi was registered in a second area of occurrence (Modesto's farm - $\left.22^{\circ} 53^{\prime} 16^{\prime \prime} \mathrm{S}, 48^{\circ} 30^{\prime} 23^{\prime \prime} \mathrm{W}\right)$, about a mile apart from the type locality (Denise de Cerqueira Rossa-Feres, unpublished data, 1982-1984). Both localities are situated in Rubião Júnior district, Botucatu, $\sim 900 \mathrm{~m}$ elevation. Recently, new records came from Brazilian states of São Paulo and Minas Gerais. Brasileiro, Martins e Jim (2008) recorded the species at Itirapina ecological station, Brotas city $\left(22^{\circ} 12^{\prime} 53^{\prime \prime} \mathrm{S} ; 4^{\circ} 54^{\prime} 41^{\prime \prime} \mathrm{W}, 750\right.$ $\mathrm{m})$, in a grassy-woody savanna area, near a gallery forest, extending about $105 \mathrm{~km}$ to the Northeast from the previously known species distribution. Carvalho Junior, Kleinsorgeand and Fusinatto (2010) found $P$. moratoi at São Carlos city $\left(22^{\circ} 01^{\prime} 00^{\prime \prime} \mathrm{S}, 47^{\circ} 56^{\prime} 21^{\prime \prime} \mathrm{W}\right.$, $810 \mathrm{~m}$ ), in an area 22 kilometers away from Brotas. Rolim et al. (2010) recorded the species at Bauru city $\left(22^{\circ} 20^{\prime} 48^{\prime \prime} \mathrm{S}, 49^{\circ} 0^{\prime} 56^{\prime \prime} \mathrm{W}, 550 \mathrm{~m}\right)$, extending about $80 \mathrm{~km}$ from its type locality and $115 \mathrm{~km}$ from the population registered at Brotas. Maffei, Ubaid and Jim (2011) recorded the species at Avaré city (22 $2^{\circ} 3^{\prime} 13^{\prime \prime} \mathrm{S}$ $48^{\circ} 56^{\prime} 48^{\prime \prime} \mathrm{W}, 675 \mathrm{~m}$ ), in an area about $45 \mathrm{~km}$ distant from its type locality. Finally, Martins and Giaretta (2012) recorded the species in four areas at the Minas Gerais state (Uberlândia, Ituiutaba, Perdizes and Monte Alegre), which extend by $350 \mathrm{~km}$ to the North of type locality (Figure 1).

Proceratophrys moratoi is endemic to Cerrado, has high specificity and low plasticity regarding environment occupation and is appointed as a "Gap species" by Silvano, Valdujo and Colli (2016), because only a very small proportion of its limited range is actually protected and these areas are extremely degraded. According Martins and Jim (2008), the species tadpoles was record only in shallow and ferruginous waters, of slow flow, between the rhizomes of cattail (habitat specialization).

The species is listed as "critically endangered" by the International Union for the Conservation of Nature - IUCN (CRUZ; CARAMASCHI, 2004). In the National List of Species of Threatened Brazilian Fauna, P. moratoi is classified as "endangered" (BRASIL, 2014). In a recent review of the São Paulo Threatened Species List, the species was removed (SÃO PAULO, 2014), possibly by new records of the species.

Despite increasing records, little is known about the ecology of P. moratoi. At its type locality, the species is not recorded since 2003 (MARTINS; JIM, 2008). However, no specific study was conducted on the species in the region and the limited information available refers to occurrence records and habitat 
occupancy (JIM; CARAMASCHI, 1980; ROSSAFERES; JIM, 1996). In this context, the objective of this study was: (1) to evaluate the conservation status of the population of P. moratoi at Botucatu, checking its possible decline, and (2) to analyze the possible causes of this decline.

\section{Material and Methods}

\section{Study sites}

The Botucatu region is part of the Paraná geological basin, Southeastern South America, varying in altitude between 500 and $1000 \mathrm{~m}$ (SEMA, 1990). The region is covered by contrasting vegetations of the Cerrado and the Atlantic Forest Biomes (ENGEA, 1990). According to Köppen classification, the climate of the region is humid subtropical ( $\mathrm{Cfa}$ ), with average annual rainfall $142.84 \mathrm{~cm}$ and average annual temperature $20.3^{\circ} \mathrm{C}$ (CUNHA; MARTINS, 2009). The rainfall is concentrated on spring and summer months (October to March), with high water contents (13 to $25 \mathrm{~cm}$ ); in the dry season (autumn and winter), water deficit occurs in the months of April, July and August (CUNHA; MARTINS, 2009). The temperature also presents seasonal behavior, averaging more than $22^{\circ} \mathrm{C}$ in the warmer months and approximately $17^{\circ} \mathrm{C}$ in the coldest month (CUNHA; MARTINS, 2009).

The study was conducted in the type locality and in the Modesto's farm, second occurrence area of Proceratophrys moratoi, both at Botucatu city, São Paulo state, southeastern Brazil (Figure 1).

\section{Habitats and microhabitats sampled}

The two localities studied resulted in a total of 16 sampled microhabitats (Figure 2):

Type locality: fountain on edge forest fragment; swamp on edge forest fragment; artificial ponds on edge forest fragment; temporary artificial pond in open area; temporary pond in open area; stream in gallery forest.

Modesto's farm: swamp on edge forest fragment; permanent and temporary ponds in open area; temporary ponds on edge forest fragment; permanent and temporary ponds in forest fragment; stream on edge forest fragment and in open area; temporary fountain in forest fragment.
Figure 1 - Geographic distribution of Proceratophrys moratoi in Brazil. In gray, the Cerrado distribution. 1) Botucatu (type locality and second occurrence area, where the species disappeared); 2) Brotas, 3) São Carlos, 4) Bauru, 5) Avaré; 6) Perdizes; 7) Uberlândia; 8) Monte Alegre de Minas; 9) Ituiutaba.

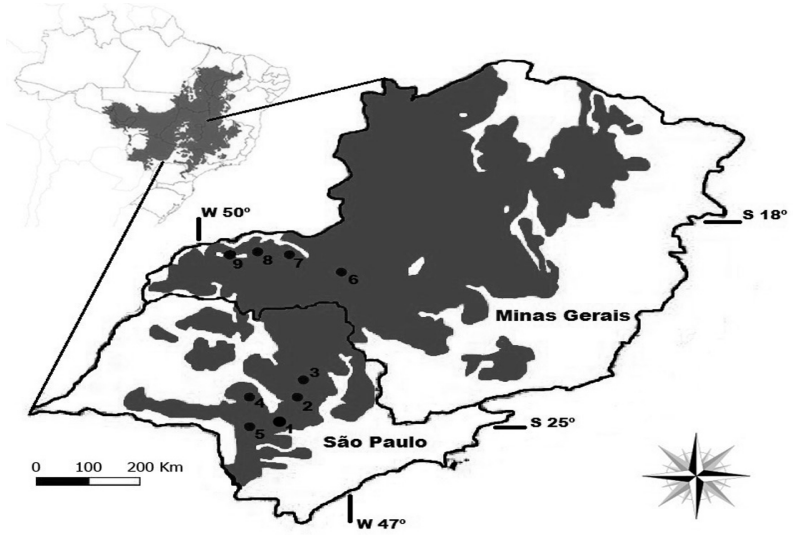

Source: Authors

Figure 2 - Type locality and Modesto's farm in Rubião Júnior district, Botucatu city, São Paulo state, southeastern Brazil.

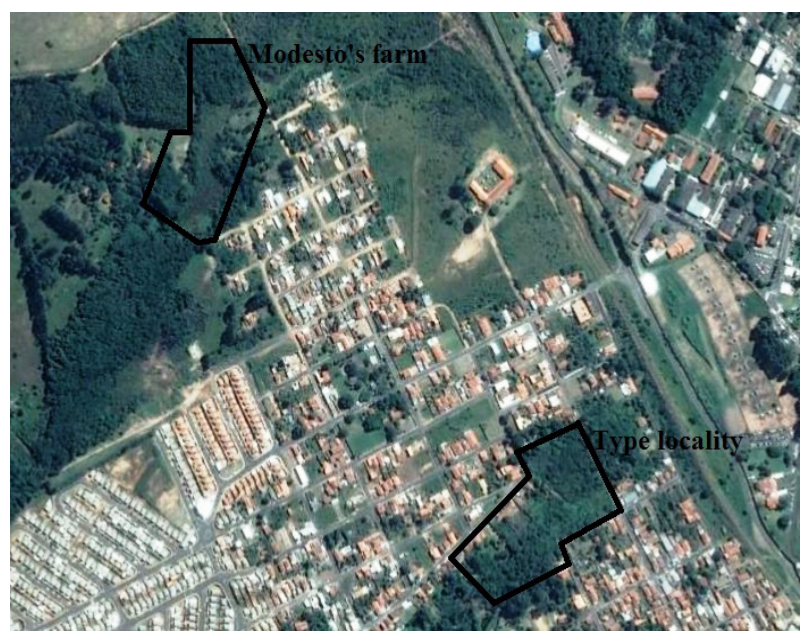

Source: Authors

\section{Sampling methods and data collection}

The work took place from August 2006 to December 2008. The samplings were made fortnightly in the rainy season and monthly during the dry season, 
summing up 34 visits at the type locality and 30 visits at the second occurrence area.

Ecological data were collected from all species of amphibians recorded at the localities sampled, summing up an active effort search of 136 hours on the type locality and 120 hours on the second area. Sampling began during daytime period, around 16:00 and stretched until nighttime, around 22:00. During daytime, shelters in aquatic environments were searched for egg masses, tadpoles and adults ("complete species inventaries” censu) (SCOTT JUNIOR, 1994). The collect of tadpoles was done monthly with the use of a sieve (diameter $32 \mathrm{~cm}$ and mesh-size 0.3 ) in different habitats. Adults were studied during the night, by traversing all microhabitats applying the methods of visual search ("visual encounter survey" censu Crump and (SCOTT JUNIOR, 1994), zoofonia ("audio strip transects" censu) (ZIMMERMAN, 1994) and sampling in breeding environments ("surveys at breeding sites" censu and woodward) (SCOTT JUNIOR, 1994).

Pitfall traps devices were installed on both areas (CECHIN; MARTINS, 2000), composed by three pitfalls (30 1 each), buried every $10 \mathrm{~m}$ and interconnected by drift-fences with $30 \mathrm{~m}$-length. There was one trap line installed at the type locality and two at the second occurrence area, totalizing a sample of 19,332 hours/bucket (type locality: 7,524 h/bucket; second occurrence area: 11,808 h/bucket).

\section{Historical data of Proceratophrys moratoi and species that coexisted with it in its type locality and in its Modesto's farm at Botucatu}

The first individual collected from Proceratophrys moratoi was captured on September 22, 1976, in the type locality, Rubião Júnior, Botucatu, São Paulo, Brazil, by Celso Morato de Carvalho. Twenty-four males and two females, collected between 1976 and 1977, were used for description the species (JIM; CARAMASCHI, 1980).

In a study by Denise de Cerqueira Rossa-Feres (unpublished data) at two areas of known occurrence of P. moratoi at Botucatu, between September 1982 and April 1984, there were obtained multiple records of the species, both in the larval and adult stages. The vocalization season of the adults occurred between September and October, when they vocalized in the same forest fragment next to the swamp. The abundance varied between one and ten individuals vocalizing in one day. The tadpoles were captured in the swamp area during the months of January, March, April, June, July, August and November. Besides $P$. moratoi, 11 species were recorded: $A$. perviridis, $D$. minutus, D. nanus, D. sanborni, $H$. albopunctatus, $H$. caingua, H. faber, S. fuscomarginatus, P. cuvieri, $L$. fuscus and L. latrans.

In the months of September and October of 1996, Jorge Jim (unpublished data) recorded an average of 6 individuals of $P$. moratoi vocalizing, in five days of sampling, in the species type locality. The following species were recorded besides $P$. moratoi at type locality: Rhinella icterica, $R$. ornata, Aplastodiscus perviridis, Dendropsophus minutus, D. sanborni, Hypsiboas albopunctatus, $H$. caingua, $H$. lundii, $H$. prasinus, Scinax fuscovarius, Physalaemus cuvieri, $P$. marmoratus, $P$. nattereri, Leptodactylus furnarius, $L$. fuscus and L. latrans (Jorge Jim, unpublished data). There was an occasional record of three individuals of P. moratoi on December 15, 1998 in the type locality (Jorge Jim, unpublished data). Jorge Jim (unpublished

Table 1 - Proceratophrys moratoi record dates in the type locality and Modesto's farm, both situated in Botucatu city, and other species records in the São Paulo (SP) and Minas Gerais (MG) states.

\begin{tabular}{|c|c|c|}
\hline Record date & Locality & Author \\
\hline Sep. 1976 & $\begin{array}{l}\text { Type } \\
\text { locality }\end{array}$ & Jim and Caramaschi (1980) \\
\hline $\begin{array}{l}\text { Sep./1982 to } \\
\text { Apr./1984 }\end{array}$ & $\begin{array}{l}\text { Modesto's } \\
\text { farm }\end{array}$ & $\begin{array}{l}\text { Denise C. Rossa-Feres } \\
\text { (unpublished data) }\end{array}$ \\
\hline Sep. and Oct. 1996 & $\begin{array}{l}\text { Type } \\
\text { locality }\end{array}$ & Jorge Jim (unpublished data) \\
\hline December 1998 & $\begin{array}{l}\text { Type } \\
\text { locality }\end{array}$ & Jorge Jim (unpublished data) \\
\hline $\begin{array}{l}\text { Sep. } 1998 \text { to Mar. } \\
2002\end{array}$ & Brotas, SP & $\begin{array}{l}\text { Brasileiro et al. 2005; Brasileiro } \\
\text { et al. } 2008\end{array}$ \\
\hline December 2001 & $\begin{array}{l}\text { Type } \\
\text { locality }\end{array}$ & Jorge Jim (unpublished data) \\
\hline November 2003 & $\begin{array}{l}\text { Type } \\
\text { locality }\end{array}$ & Martins and Jim, 2008 \\
\hline $\begin{array}{l}\text { Dec./2005; } \\
\text { Sep./2008; } \\
\text { Oct./2011 }\end{array}$ & $\begin{array}{l}\text { Uberlândia, } \\
\text { MG }\end{array}$ & $\begin{array}{l}\text { Martins and Giaretta, 2008; } \\
\text { Martins and Giaretta, } 2012\end{array}$ \\
\hline Aug. to Oct./2011 & $\begin{array}{l}\text { Ituiutaba, } \\
\text { MG }\end{array}$ & Martins and Giaretta, 2012 \\
\hline $\begin{array}{l}\text { Nov. } 2008 \text { and Jan. } \\
2009\end{array}$ & Bauru, SP & Rolim et al. 2010 \\
\hline October 2009 & Avaré, SP & Maffei et al. 2011 \\
\hline
\end{tabular}

Source: Authors 
data) recorded occasionally the species vocalizing in type locality for the last time in December, 2001 and the last individual recorded, not vocalizing, to type locality was November, 2003 (MARTINS; JIM, 2008).

\section{Disappearance of $P$. moratoi in its type locality and its second occurrence area at Botucatu}

The two areas of occurrence of $P$. moratoi were thoroughly sampled for tadpoles and adults, but no individuals were recorded in between August 2006 to December 2008.

When comparing historical data and the data from the present study, it is noticed the disappearance of $P$. moratoi at the two areas, besides that $A$. perviridis disappeared from the type locality of $P$. moratoi and declined in the Chácara do Modesto . Tadpoles of $A$. perviridis were recorded in the same body of water than P. moratoi and they were also not found in this study. The other species occurring in the same environment of $P$. moratoi did not disappeared or declined.

\section{Environmental Changes}

Several environmental changes have been observed in the two localities of P. moratoi at Botucatu. At type locality, the main changes observed were: 1) pollution due to urbanization in the surrounding swamp; 2) colonization by the exotic swamp lily (Hedychium coronarium) which took the place of cattail (Typha dominguensis) in the swamp, which was very abundant at the site; 3) water flow modification through piping or draining, turning wetlands into areas for vegetable cultivation and pasture for cattle and horses; and 4) the swamp silting, caused by the removal of natural vegetation surrounding the area, when much of the sediment was transported to the swamp by the rain. The water level has decreased and do not form anymore the small puddles from water that poured slowly between the roots of cattail. The sediment accumulation at the site made the water muddier. Finally in 2008, the dirt streets were paved in the vicinity, it was built dump rainwater pipe and a possible project was started to build a road that would run through the swamp area (Figure 3). However, this work was not finished until October, 2008. In april of 2017, a visit to the type locality was made and it was observed that the street was not built and the area is covered by exotic vegetation in the place that had been cleared.
Figure 3 - Dirt street paved around the area and rainwater pipe built.

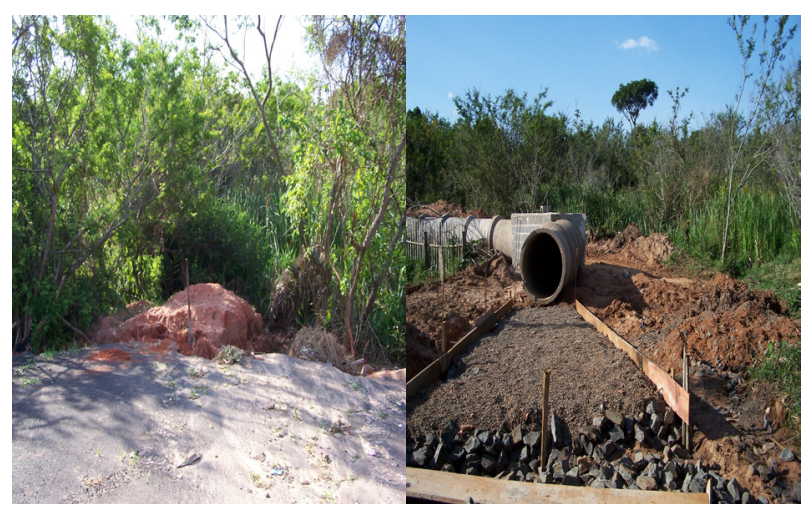

Source: Authors

The second occurrence area faced changes in its vicinity, which was deforested for house building. Locally, soil transport to the swamp caused silting and water level decrease, and households dump sewage into the swamp. Furthermore, cattle transit and graze through the whole area, changing the marginal and core swamp vegetation. Finally, the once monodominant cattail (Typha dominguensis) was substituted by sedges and grasses, preventing the entry of sunlight in the water.

\section{Discussion}

The main signs of P. moratoi disappearance from the known occurrence areas in Botucatu were the drastic environmental changes that occurred at these areas. Several cases of population decline or disappearance of amphibian species have been documented worldwide (COHEN JUNIOR, 2001; YOUNG et al., 2001). However, the loss, decharacterization and fragmentation of habitats is considered by many authors as the main threats to amphibian species (BECKER et al., 2007; VALLAN, 2002). The anthropic pressure at Botucatu was intense, fragmenting and changing the landscape of P. moratoi.

Several studies demonstrate the susceptibility of amphibian species in relation to man-made environmental impacts. In Europe, the main evidence of Bufo calamita decline was the loss of habitat (BEEBEE, 2002; DENTON et al., 1997). In Italy, the main factor for the amphibians populations decline was the changes in habitat resulting from human actions (D'AMEN; PIETRANGELI; BOLOGNA, 
2010). Some cases of decline and disappearance were cited by Eterovick et al. (2005) in Brazil. In the last decade, the impacts due to human activities were very intense in Botucatu places of P. moratoi.

Major changes had occurred in the study areas, even before the species was discovered and described. In 1976, the year that the species was first found, the site had suffered anthropogenic changes due to neighbour dwellings and deforestation for agricultural expansion. The last record of the species at Botucatu was an individual found at random in its type locality in 2003, which was not in calling activity (MARTINS; JIM, 2008). This shows that the species probably was in decline even before it was described, persisting in the place for some years and disappearing recently.

The breeding microhabitats of the species suffered drastic changes over the years, as the flow and the volume of water from the water bodies, which possibly affected the survival of tadpoles in the community. Thus, those species with greater environmental plasticity on remained, while sensible species (like A. perviridis and $P$. moratoi) suffered from changes in their habitat do to their lower ecological plasticity. Both species possibly did not adapt to the new environmental conditions, so declined and disappeared from the local.

Many amphibian communities were studied at Botucatu by Jim (2002) and Almeida (2010). Jim (2002) conducted 869 surveys in 39 areas between 1968 and 2001 and Almeida (2010) conducted 495 surveys at 29 locations between 1998 and 2009 (excluding the two areas of $P$. moratoi) and did not record the species in any of the surveyed localities. These facts reinforces the hypothesis of species declination in the region, wich probably is associated to the high environmental specificity and low plasticity of $P$. moratoi.

The species no longer occur in Botucatu; however, it was recorded in four more new locations in São Paulo state (BRASILEIRO; MARTINS; JIM, 2008; CARVALHO JUNIOR; KLEINSORGEAND; FUSINATTO, 2010; MAFFEI; UBAID; JIM, 2011; ROLIM et al., 2010) and four locations in Minas Gerais state (MARTINS; GIARETTA, 2012). In these areas, the species was recorded in vocalization activity on Cerrado environments (Fig. 1). At the new occurrence areas in São Paulo, the species was recorded associated with fountain areas, similar to what was recorded at the two Botucatu localities (JIM, 1980, 2002; JIM; CARAMASCHI, 1980; ROSSA-FERES; JIM, 1996).
According to Martins and Giaretta (2012), the species can resist human impact and can colonize altered environments, as it was recorded in disturbed urban areas. However, P. moratoi also occupied altered areas around Botucatu where it is currently absent. The species occurrence in modified areas depends on the integrity of breeding habitat and nurse water bodies where tadpoles develop. P. moratoi persisted for 27 years in a modified habitat, however, when the impacts affected its reproduction and ontogeny, the species disappeared.

The elevational amplitude where the species occurs in São Paulo is significant, ranging from 550 to $900 \mathrm{~m}$ of altitude (ROLIM et al., 2010). However, the environments used by the species are very similar in relation to biotic and abiotic factors, especially in the grassy-woody savanna ("campo sujo") of the Cerrado biome. These data demonstrate the need to preserve areas where the species occurs, coupled with the preservation of Cerrado areas in São Paulo state, especially the fountain areas on "campo sujo", as it guarantees the P. moratoi population survival.

Botucatu is the southernmost locality of P. moratoi, coinciding with the southeastern limit of Cerrado biome. Being a borderline area of distribution of the species, environmental variables are limiting factors in the distribution of P. moratoi. The sum of anthropogenic changes plus natural limiting factors possibly created an unsuitable environment for the species, wich requires specific features for its existence. The species occurs in open Cerrado phytophysiognomies (BRASILEIRO; MARTINS; JIM, 2008). Botucatu is in a transition area of the Cerrado with the Atlantic Forest, with a predominance of the latter (SINBIOTA, 2017), restricting the number of areas favorable to the occurrence of $P$. moratoi.

The return of P. moratoi to the List of Endangered Species of São Paulo state, as well as the implantation of new protected areas of Cerrado, chosed according the presence of the species and the environmental features needed for its long term survival.

\section{Acknowledgments}

We want to thank the Conservation International Brazil and PEQUI (Pesquisa e Conservação do Cerrado) for the financial support, and Instituto Brasileiro do Meio Ambiente e dos Recursos Naturais Renováveis (IBAMA) for authorization to conduct this study (authorization number 004/07 IBAMA/RAN). 


\section{References}

ADAMS M. J. Correlated factors in amphibian decline: exotic species and habitat change in western Washington. Journal Wildlife Management, London, v. 63, p. 1162-1171, 1999.

ALMEIDA S. C. Ecology of Lithobates catesbeianus (Shaw, 1802) and relations with the amphibians of Botucatu region, SP (Amphibia, Anura). 2010. 79 f. PhD Dissertation, Instituto de Biociências Universidade Estadual Paulista, Botucatu, São Paulo, Brazil, 2010.

ARAÚJO, M. B.; THUILLER, W.; PEARSON, R. G. Climate warming and the decline of amphibians and reptiles in Europe. Journal of Biogeography, Malden, v. 33, p. 1712-1728, 2006.

BECKER, C. G.; FONSECA, C. R.; HADDAD, C. F. B.; BATISTA, R. F.; PRADO, P. I. Habitat split and the global decline of amphibians. Science, Washington, v. 318, p. 1775-1777, 2007.

BEEBEE, T. J. C. The natterjack toad Bufo calamita in ireland: current status and conservation requirements. Irish Wildlife Manuals, Ireland, n. 10, 2002.

BEEBEE, T. J. C.; FLOWER, R. J.; STEVENSON, A. C.; PATRICK, S. T.; APPLEBY, P. G.; FLETCHER, C.; MARSH, C.; NATKANSKI, J.; RIPPEY, B.; BATTARBEE, R. W. Decline of the Natterjack toad Bufo calamita in Britain: Paleoecological, documentary and experimental evidence for breeding site acidification. Biological Conservation, Amsterdam, v. 53, p. 1-20, 1990.

BLAUSTEIN, A. R.; HOKIT, D. G.; KIESECKER, J. F.; WALLS, S. C.; HAYS, J. B. Uv repair and resistence to solar uv-b in amphibians eggs: a link to populations declines? Proceedings of the National Academy of Sciences of the United States of America, Washington, v. 91, p. 1791-1795, 1994.

BOONE, M. D.; JAMES, S. M. Interactions of an insecticide, herbicide, and natural stressors in amphibian community Mesocosms. Ecological Applications, Washington, v. 13, p. 829-841, 2003.
BRASIL. Ministério do Meio Ambiente. Lista das espécies da fauna brasileira e a lista dos peixes e invertebrados aquáticos ameaçados de extinção. Diário Oficial da União, Brasília, p. 121-126, 2014. Available in: <www.e-diariooficial.com $>$. Acessed in: 2 Jan. 2017.

BRASILEIRO, C. A.; MARTINS, I. A.; JIM, J. Amphibia, Anura, Cycloramphidae, Odontophrynus moratoi: distribution extension and advertisement call. Check List, São Paulo, v. 4, p. 382-385, 2008.

BRODMAN, R.; CORTWRIGHT, S.; RESETAR, A. Historical changes of reptiles and amphibians of northwest indiana fish and wildlife properties. The American Midland Naturalist, Indiana, v. 147, p. 135144, 2002.

CAREY, C. Hypothesis concerning the causes of the disappearance of Boreal Toads from the Mountains of Colorado. Conservation Biology, Washington, v. 7, p. 355-362, 1993.

CARVALHO JUNIOR, R. R.; KLEINSORGEAND, J. M. D.; FUSINATTO, L. A. Amphibia, Anura, Cycloramphidae, Odontophrynus moratoi Jim and Caramaschi, 1980: filling gaps. Discovery of a new population in the state of São Paulo, southeastern Brazil. Check List, São Paulo, v. 6, p. 36-37, 2010.

CECHIN, S. Z.; MARTINS, M. Eficiência de armadilhas de queda (pitfall traps) em amostragens de anfíbios e répteis no Brasil. Revista Brasileira de Zoologia, Curitiba, v. 17, p. 729-740, 2000.

COHEN JUNIOR, M. M. Frog decline, frogmalformations, and a comparison of frog and human health. American Journal of Medical Genetics, Malden, v. 104, p. 101-109, 2001.

CRAWFORD, A. J.; LIPS, K. R.; BERMINGHAM, E. Epidemic disease decimates amphibian abundance, species diversity, and evolutionary history in the highlands of central Panama. Proceedings of the National Academy of Sciences of the United States of America, Washington, v. 31, p. 13777-13782, 2010. 
CRUMP, M. L.; SCOTT JUNIOR, N. J. Visual encouter surveys. In: HEYER, W. R.; DONNELY, M. A.; MCDIARMID, R. W.; HAYEK, L. C.; FOSTER M. S. Measuring and monitoring biological diversity: standart methods for amphibians. Washington: Smithsonian Institution Press, 1994. p. 84-92.

CRUZ, C. A. G., CARAMASCHI, U. The IUCN red list of threatened species. Version 2016-1. 2004. Available in: <www.iucnredlist.org >. Accessed in: 29 Dec. 2016.

CUNHA, A. R.; MARTINS, D. Classificação climática para os municípios de Botucatu e São Manuel, SP. Irriga, Botucatu, v. 14, p. 1-11, 2009.

D’AMEN, M.; PIETRANGELI, B.; BOLOGNA, M. A. Human-provoked amphibian decline in central Italy and the efficacy of protected areas. Wildlife Research, Melbourne, v. 37, p. 547-557, 2010

DENTON, J. S.; HitChingS, S. P.; BEEBEE, T. J. P.; GENT, A. A Recovery program for the Natterjack Toad (Bufo calamita) in Britain. Conservation Biology, Washington, v. 11, p. 1329-1338, 1997.

ENGEA. Avaliação, Estudos do Patrimônio e Engenharia. Levantamento e análise dos quadros ambientais e proposições físico territoriais de zoneamento ambiental para a APA CorumbataíBotucatu-Tejupá, perímetro Botucatu. São Paulo: SMA, 1990. v. 2.

ETEROVICK, P. C.; CARNAVAL, A. C. O. Q.; BORGES-NOJOSA, D. M.; SILVANO, D. L.; SEGALLA, M. V. SAZIMA, I. Amphibian declines in Brazil: na overview. Biotropica, Malden, v. 37, p. 166179, 2005.

GREEN, D. M. The ecology of extinction: population fluctuation and decline in amphibians. Biological Conservation, Amsterdam, v. 111, p. 331-343, 2003.

HARTE, J.; HOFFMAN, E. Possible effects of acidic deposition on a rocky mountain population of the tiger salamander Ambystoma tigrinum. Conservation Biology, Washington, v. 3, p. 149-158, 1989.
HAYES, T. B. Steroid-mimicking environmental contaminants: their potential role in amphibian declines. In: BOHME, W.; BISCHOFF, W.; ZIEGLER, T. Herpetologia bonnensis. Bonn: Societas Europaea Herpetologica, 1997. p. 145-149.

HEYER, W. R.; RAND, A. S.; CRUZ, C. A. G.; PEIXOTO, O. L. Decimations, extinctions and colonizations of frog populations in southeast Brazil and their evolutionary implications. Biotropica, Malden, v. 20, p. 230-235, 1988.

HOULAHAN, J. E.; FINDLAY, C. S.; SCHMIDT, B. R.; MEYERS, A. H.; KUZMINK, S. L. Quantitative evidence for global amphibian population declines. Nature, New York, v. 404, p. 752-755, 2000.

JENNINGS, M. R.; HAYES, M. P. Pre-1900 overharvest of california red-legged frogs (Rana aurora draytonii): the inducement for bullfrog (Rana catesbeiana) introduction. Herpetologica, Lawrence, v. 41, p. 94-103, 1985.

JIM, J. Altitudinal distribution and long-term study of amphibians from Botucatu, State of São Paulo. 2002. 332 f. PhD (Dissertation) - Instituto de Biociências, Universidade Estadual Paulista, São Paulo, 2002.

JIM, J. Ecological aspects of amphibian recorded in the region of Botucatu, São Paulo. 1980. 162 f. PhD (Dissertation) - Instituto de Biociências, Universidade Estadual Paulista, São Paulo, 1980.

JIM, J.; CARAMASCHI, U. Uma nova espécie de Odontophrynus da região de Botucatu, São Paulo, Brasil (Amphibia, Anura). Revista Brasileira de Biologia, São Carlos, São Paulo, v. 40, p. 357-360, 1980 .

KATS, L. B.; FERRER, R. P. Alien predators and amphibian declines: review of two decades of science and the transition to conservation. Diversity and Distributions, Malden, v. 9, p. 99-110, 2003.

LIPS, K. R. Decline of a tropical montane amphibian fauna. Conservation Biology, Washington, v. 12, p. 106-117, 1998. 
LIPS, K. R. Mass mortality and population declines of anurans at an upland site in western Panama. Conservation Biology, Washington, v. 13, p. 117-125, 1999.

LIPS, K. R.; BURROWES, P. A.; MENDELSON, J. R. III; PARRA-OLEA, G. Amphibian declines in Latin America: Widespread population declines, extinctions, and impacts. Biotropica, Malden, v. 37, p. 163-165, 2005.

LIZANA, M.; PEDRAZA, E. P. The effects of UV-B radiation on toad mortality in mountainous areas of central spain. Conservation Biology, Washington, v. 12, p. 703-707, 1998.

MAFFEI, F.; UBAID, F. K.; JIM, J. Discovery of the fifth population of a threatened and endemic toad of the Brazilian Cerrado, Proceratophrys moratoi (Anura, Cycloramphidae). Herpetology Notes, Bonn, v. 4, p. 95-96, 2011.

MARSH, D. M. Fluctuations in amphibian populations, meta-analysis. Biological Conservation, Amsterdam, v. 101, p. 327-335, 2001.

MARTINS, I. A.; JIM, J. Proceratophrys moratoi. In: MACHADO,A.B.M.;DRUMMOND, G. M.; PAGLIA, A. P. Livro vermelho da fauna brasileira ameaçada de extinção. Brasília: Fundação Biodiversitas, 2008. p. 286-325.

MARTINS, L. B.; GIARETTA, A. A. Advertisement calls of two species of proceratophrys (Anura: Odontophrynidae) from Minas Gerais, Brazil, with comments on their distribution, taxonomy and conservation status. South American Journal of Herpetology, São Paulo, v. 7, n. 3, p. 203-212, 2012.

MARTINS, L. B.; GIARETTA, A. A. História natural de uma espécie de proceratophrys (Anura, Alsodinae) do bioma Cerrado. In: ENCONTRO INTERNO, 7., SEMINÁRIO DE INICIAÇÃO CIENTÍFICA DA UNIVERSIDADE FEDERAL DE UBERLÂNDIA, 13., 2008, Uberlândia. Anais... Uberlândia: UFB, 2008. p. 1-10.
PEACHMANN, J. H. K.; SCOTT, D. E.; SEMLITSCH, R. D.; CALDWELL, J. P.; VITT, L. J.; GIBBONS, J. W. declining amphibian populations: the problem of separating human impacts from natural fluctuations. Science, Washington, v. 253, p. 892-895, 1991.

PISTONI, J.; TOLEDO, L. F. Amphibian illegal trade in Brazil: what do we know? South American Journal of Herpetology, Washington, v. 5, p. 51-56, 2010.

POUNDS, J. A. Conservation of the golden toad: a brief history. British Herpetological Bulletin, Montrose, v. 55 , p. 5-7, 1996.

POUNDS, J. A.; CRUMP, M. L. Amphibian declines and climate disturbance: the case of the golden toad and the harlequin frog. Conservation Biology, Washington, v. 8, p. 72-85, 1994.

POUNDS, J. A.; FOGDEN, M. P. L.; CAMPBELL, J. $\mathrm{H}$. Biological response to climate change on a tropical mountain. Nature, New York, v. 398, p. 611-615, 1999.

PRIMACK, R. B.; RODRIGUES, E. Biologia da conservação. Londrina: Planta, 2001.

ROLIM, D. C.; MARTINEZ, R. A. M.; ALMEIDA, S. C.; UBAID, F. K.; MAFFEI, F.; JIM, J. Amphibia, Anura, Cycloramphidae, Proceratophrys moratoi (Jim and Caramaschi, 1980) distribution extension and new altitudinal record in state of São Paulo, Brazil. Check List, São Paulo, v. 6, p. 576-578, 2010.

ROSSA-FERES, D. C.; JIM, J. Tadpole of Odontophrynus moratoi (Anura, Leptodactylidae). Journal of Herpetology, Ohio, v. 30, p. 536-539, 1996.

SALAS, A. W. Herpetofauna peruana: una visión panorámica sobre investigación, conservación y manejo. Biotempo, Lima, v. 2, p. 125-137, 1995.

SÃO PAULO. Decreto $n^{\circ}$ 60133, de 7 de fevereiro de 2014. Declara as espécies da fauna silvestre ameaçadas de extinção, as quase ameaçadas e as deficientes de dados para avaliação no Estado de São Paulo e dá providências correlatas. Diário Oficial do Estado de São Paulo, São Paulo, seção 1, v. 124, n. 27, p. 25-32, 2014. 
SCOTT JUNIOR, N. J. Complete species inventories. In: HEYER, W. R.; DONNELLY, M.A.; MCDIARMID, R. W.; HAYEK, L. C.; FOSTER, M. S. Measuring and monitoring biological diversity: standard methods for amphibians. Washington: Smithsonian Institution Press, 1994. p. 78-84.

SHERMAN, C. K.; MORTON, M. L. Population Declines of yosemite toads in the eastern sierra nevada of California. Journal of Herpetology, Ohio, v. 27, p. 186-198, 1993.

SILVANO, D. L.; VALDUJO, P. H.; COLLI, G. R.; Priorities for conservation of the evolutionary history of amphibians in the Cerrado. In: PELLENS, R.; GRANDCOLAS, P. Biodiversity conservation and phylogenetic systematics: Preserving our evolutionary heritage in an extinction crisis (Topics in Biodiversaty and Conservation). New York: Springer, 2016. p. 287 305 .

SINBIOTA. Sistema de informação ambiental do

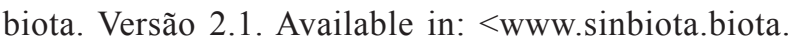
org.br>. Accessed in: 7 Apr. 2017.

SPARLING, D. W. Acidic deposition: a review of biological effects. In: HOFFMAN, D. J.; RATTNER, B. A.; BURTON JUNIOR, G. A. ; CAIRNS JUNIOR, J. Handbook of ecotoxicology. Boca Raton: Lewis Publishers, 1995. p. 321-329.

VALLAN, D. Effects of anthropogenic environmental changes on amphibian diversity in the rain forests of eastern Madagascar. Journal of Tropical Ecology, Cambridge, v. 18, p. 725-742, 2002.

WEYGOLDT, P. Changes in the composition of moutain stream frog communities in the Atlantic moutains of Brazil: frogs as indicators of environmental deteriorations? Studies on Neotropical Fauna and Environment, Oxfordshire, v. 243, p. 249-255, 1989.

YOUNG, B. E.; LIPS, K. R.; REASER, J. K.; IBÁÑEZ, R.; SALAS, A. W.; CEDEÑO, J. R.; COLOMA, L. A.; RON, S.; LA MARCA, E.; MEYER, J. R.; MUÑOZ, A.; BOLAÑOS, F.; CHAVES, G.; ROMO D. Population declines and priorities for amphibian conservation in Latin America. Conservation Biology, Washington, v. 15, p. 1213-1223, 2001.
ZIMMERMAN, B. L. Áudio strip transects. In: HEYER, W. R.; DONNELLY, M. A.; MCDIARMID, R. W.; HAYEK, L. C.; FOSTER, M. S. Measuring and monitoring biological diversity: standart methods for amphibians. Washington: Smithsonian Institution Press, 1994. p. 92-97. 